\title{
Improving Corporate Image: The role of Suitability of Social Responsibility Program
}

\author{
Anik Lestari Andjarwati \\ Universitas Negeri Surabaya \\ Surabaya, Indonesia \\ aniklestari@unesa.ac.id
}

\author{
Rosa Prafitri Juniarti \\ Universitas Negeri Surabaya \\ Surabaya, Indonesia \\ rosajuniarti@unesa.ac.id
}

\begin{abstract}
This study aims to understand the suitability of CSR conducted by companies with the expertise area in influencing the company's image. This study used a betweensubject experiment (CSR suitability: high, low). The research participants were S1 Management students from Universitas Negeri Surabaya. The stimulus was given in a form of information about CSR and the organizing company. Participants' evaluation was obtained using a questionnaire. Data were analyzed by employing different tests with SPSS software. The hypothesis could be proven in this study. The suitability of CSR with the area of experties companies could improve the company's image.
\end{abstract}

Keywords—corporate image; CSR

\section{INTRODUCTION}

Images can be described as meaningful networks stored in memory, ranging from holistic to complex object evaluations [1]. Meanwhile, a corporate image is a mental picture of a company made by different audiences [2]. To create a corporate image, companies use marketing resources and internal activities to build the desired image in the minds of stakeholders [3].

According to Rangkuti, the factors that influence a corporate image include the prices offered, guarantees for quality services, physical facilities' appearance, and organizational commitment [4]. How a company looks is very important because the image itself is the most important nonphysical asset that must be owned by the company [4]. Meanwhile, according to Peter, Olson, \& Grunet, several factors determining a corporate image include leadership, policy and strategy, policy and personnel, asset management, management process, customer satisfaction, business satisfaction, business results, and social responsibility [5].

CSR which is in accordance with the company's brand association can facilitate the transfer of positive influence from CSR to the company [6]. The relationship between the twos is able to influence the company's brand association and subsequently is able to increase a more positive consumer evaluation to the company. In other words, it improves the corporate image. The suitability of CSR with companies can encourage the perception that companies will lend their expertise to a CSR program and this will cause consumers to associate the company's main competencies with CSR programs and believe that the company will fulfill its promises to carry out CSR [7]. This study aims to increase understanding about the influence of CSR conformity and corporate image.

\section{LITERATURE REVIEW}

\section{A. Corporate Social Responsibility}

CSR is a specific form of responsibility which is a multirelational assumption including the subject, object, authority, of which the criteria cover a person who has an obligation to do something towards someone on the basis of a certain normative standard [8].

Previous research explained that organizations that carried out CSR received positive benefits [9], including increasing brand equity [10] and customer loyalty [11], positive evaluations of consumers about their organization and products [12], customer identification [13], closer relations between company and related stakeholders that can further affect the supply sources [14], the effect of company products and services [12], the creation of corporate support in the event of a business failure [15], increased brand differentiation [16] and competitive advantage [17], as well as improving financial performance [18].

\section{B. CSR Suitability}

The CSR's suitability can probably be seen either from its function or its image. Functional-based suitability occurs when the product or sponsor brand service is used by its causality beneficial receiver; meanwhile image-based suitability occurs when the brand mark is equal with the causality of product sender or the direct services which is being used by its receiver [19]. The functional and image suitability is determined by its product functional compatibility and its causality, while the image is determined by the brand characteristic and its causality [20]. The CSR's suitability which is discussed in this research is the functional suitability.

\section{Corporate Image}

Corporate image is all impression of corporation which is being made by the consumers [21]. In other word, it is an entire consumer' assessment and evaluation of corporate. The corporate doesn't reflect its single image, but many images [23]. The CSR can increase the corporate image because 
consumers are prone to connect several kind of associations that is linked with the image of the brand through such program [24].

CSR which is suitable with the corporate brand association can facilitate such positive influence transfer from the CSR to the corporate [6]. Both connection, can manipulate such corporate brand association and further can improve the positive consumers' evaluation to the corporate or in the other word the image of corporate. CSR's suitability with such corporate can boost such perception that corporate would invest expertise to the CSR program and that issue will invite consumers to associate the main competence of corporate with CSR program and they will believe that the corporate would keep its promise to conduct such CSR [7]. In the recent time, the main goal of corporate is to gain such benefit as much as possible and the increasing corporate image would guarantee its sustainable growth and development when the corporate give such attention in term of economic, social, and environmental aspect. The society is now able to judge to such degree the corporate contribution to the society's and environmental importance. CSR nowadays is identical with how much money spent by corporate. CSR is not only seen from how much money from the corporate, but it also seen from its intangible judgment which is very crucial connecting to how far such active and proactive corporate with their surrounding environment. Based on that issue, several corporate nowadays are having or conducting CSR program as a commitment and responsibility in term of its contribution in economic, social, and environmental aspect. By conducting $\mathrm{CSR}$, it is expected that society would likely to support and also affect positively to the image of corporate

H1: The CSR's suitability with corporate expertise field that is likely to improve its image.

\section{METHOD}

This study is cross-sectional research where data gathering from the samples was only done once, or in exact term, the empirical data was gained from each participant in one moment. The method of this research is quantitative. The quantitative method used in this study was experiment which is a causal research that is used to explore causality [25].

The corporate field in this research was telecommunication provider. The product categorization of telecommunication provider was chosen because from the observation result, telecommunication provider is the product which is becoming the participants' needs, brought anywhere, and is used in any kind of activities. The corporate used was fictive one. This is to protect and prevent such bias of familiar brand.

The CSR chosen for the experiment in this research was free-Wi-Fi area supplying in a public medium to CSR with high suitability and CSR grant in term of scholarship with low suitability. The pre-test was done with focus group with ten undergraduate students and expert justification.

The stimulus used in this research was information. The questionnaire was used to evaluate response and to check the suitability of manipulation.
The experiment was done in the classroom involving 60 participants ( 2 rooms with 30 participants of each). Before the main test experiment was done, the pretest had been done to determine the corporate and CSR with high and low suitability.

The main test experiment was done by giving such stimuli in term of text about the explanation of corporate and implemented CSR and was continued by measuring variables with questionnaires.

The main study was carried out at the Faculty of Economics, State University of Surabaya by distributing two different questionnaires according to the cells studied. All participants were students of Faculty of Economy Management UNESA to maintain the homogeneity of participants. Filling out the questionnaire is done after the class is finished. Before being given to participants, the questionnaire has been randomized in such a way that neither the researcher nor the participant can choose a particular type of questionnaire. Except for the type of questionnaire and stimulus in the questionnaire, each participant received the same treatment. After all participants answered the questionnaire and returned them, participants were given debriefing, namely information that they had participated in the experimental research and what they saw in the stimulus and questionnaire that had been modified for research purposes only. Participants were also asked not to discuss the contents of the study because the data collection process would still take place.

In this study, the company's image response variable is measured by an impression, trust, and feeling. Meanwhile, checking CSR suitability manipulation is measured by the appropriate indicator (suitable) and complementing (complement).

The initial analysis aims to find out whether participants fulfill the requirements as research objects. This analysis consists of awareness checks, to ensure that participants see the treatment given in the study. Of the 80 questionnaires that were filled in by the participants, all questionnaires that passed the initial analysis, namely participants answered the questions correctly regarding the stimulus used in the experiment. The distribution of participants into experimental cells was 40 participants per experiment.

\section{RESULTS AND DISCUSSION}

Manipulation tests are conducted to ensure that the manipulation done in this study is successful. The results showed that all manipulations in this study were successful. This can be seen in the average difference of each manipulated factor and the significance value of the independent sample $t$ test $<0.05$. The complete results can be seen in table 1 and table 2 below. 
TABLE I.

DIFFERENCES IN MANIPULATION TEST AVERAGE CSR FIT

\begin{tabular}{|c|c|c|c|c|c|}
\hline & Sel & $\mathbf{N}$ & Mean & $\begin{array}{c}\text { Std. } \\
\text { Deviation }\end{array}$ & $\begin{array}{c}\text { Std. Error } \\
\text { Mean }\end{array}$ \\
\hline \multirow{2}{*}{ fit } & High-fit & 40 & 11.4250 & 3.11232 & .49210 \\
\cline { 2 - 6 } & Low-fit & 40 & 8.1500 & 3.56299 & .56336 \\
\hline
\end{tabular}

TABLE II. MANIPULATION TEST CSR Fit

\begin{tabular}{|c|c|c|c|c|c|c|c|c|c|c|}
\hline & \multicolumn{2}{|c|}{$\begin{array}{c}\text { Levene's } \\
\text { Test for } \\
\text { Equality } \\
\text { of } \\
\text { Variances }\end{array}$} & \multicolumn{7}{|c|}{ t-test for Equality of Means } \\
\hline & & \multirow[t]{2}{*}{$F$} & \multirow[t]{2}{*}{ Sig. } & \multirow[t]{2}{*}{$t$} & \multirow[t]{2}{*}{$D f$} & \multirow[t]{2}{*}{$\begin{array}{c}\text { Sig. } \\
(2- \\
\text { tailed })\end{array}$} & \multirow{2}{*}{$\begin{array}{c}\text { Mea } \\
n \\
\text { Diff } \\
\text { eren } \\
\text { ce }\end{array}$} & \multirow{2}{*}{\begin{tabular}{|c} 
Std. \\
Erro \\
$r$ \\
Diff \\
eren \\
ce
\end{tabular}} & \multicolumn{2}{|c|}{$\begin{array}{c}95 \% \\
\text { Confidence } \\
\text { Interval of the } \\
\text { Difference }\end{array}$} \\
\hline & & & & & & & & & Lower & Upper \\
\hline \multirow{2}{*}{ fit } & $\begin{array}{c}\text { Equal } \\
\text { variance } \\
\quad s \\
\text { assumed }\end{array}$ & .011 & .916 & 4.378 & 78 & .000 & $\begin{array}{r}3.27 \\
500\end{array}$ & $\begin{array}{r}.748 \\
02\end{array}$ & $\begin{array}{r}1.785 \\
80\end{array}$ & $\begin{array}{r}4.764 \\
20\end{array}$ \\
\hline & $\begin{array}{c}\text { Equal } \\
\text { variance } \\
\text { s not } \\
\text { assumed }\end{array}$ & & & 4.378 & $\begin{array}{r}76.6 \\
16\end{array}$ & .000 & $\begin{array}{r}3.27 \\
500\end{array}$ & $\begin{array}{r}.748 \\
02\end{array}$ & $\begin{array}{r}1.785 \\
38\end{array}$ & $\begin{array}{r}4.764 \\
62\end{array}$ \\
\hline
\end{tabular}

Hypothesis 1 test results using independent sample ttest shows that hypothesis 1 which reads the suitability of CSR with the company's expertise will improve the company's image can be proven by research data.

Hypothesis 1 which was the suitability of CSR with the area of expertise of the company will improve the company's image can be proven in this study. The result is in line with the previous studies. CSR which is in accordance with the company's brand association, can facilitate the transfer of positive influence from CSR to the company [6]. The relationship between two companies is able to influence the company's brand association and is able to improve a more positive consumer evaluation to the company or in other words improve the company's image subsequently [7]. The suitability of CSR with companies is able to encourage perceptions that companies will lend their expertise to a CSR program and this will be able to persuade the consumers to associate the company's main competencies with CSR programs and to believe that the company will fulfill its promises to carry out CSR [7].

\section{CONCLUSION}

Hypothesis 1 which was the suitability of CSR with the area of expertise of the company will improve the company's could be proven through this study. Subsequent research can focus on the suitability of the CSR brand image and program or by using CSR advertising stimuli because consumers and audiences often know CSR communication from company advertisements on CSR. The type of advertising stimulus used is also interesting to be studied.

\section{REFERENCES}

[1] J. Cornelissen, "Corporate image: an audience centred model," Corporate Communications: An International Journal., pp. 119-125, 2000 .

[2] E. R. Gray and J. M. T. Bray, "Managing corporate image and corporate reputation," Long Range Planning., vol. 31, no. 5, pp. 695-702, 1998

[3] G. Dowling, "Measuring corporate images: A review of alternative approaches," Journal of Business Research., vol. 17, pp.27-34, 1988.

[4] F. Rangkuti, Teknik Mengukur dan Strategi Meningkatkan Kepuasan. Pelanggan. Jakarta : Penerbit PT Gramedia Pustaka Utama, 2008.

[5] J. P. Peter, J. C. Olson, and K. Grunet, Consumer behaviour and marketing strategy: European edition. London: McGraw Hill, 1999.

[6] B. A. Lafferty, R. E. Goldsmith, "Cause-brand alliances: does the cause help the brand or does the brand help the cause?" Journal of Business Research., vol. 58, no. 4, pp. 423-429, 2005.

[7] T. Lu, X. Wei, and Li. K, "Consumer responses to corporate social responsibility programs: The influence of company-cause fit and consumer involvement," Nankai Business Review International., vol. 6 , no. 3, pp. 2001-2012, 2015.

[8] P. Bachmann, and D. Ingenhoff, "Corporate social responsibility and media responsibility: An innovative classification of responsibility regarding media corporations," in 63rd Annual Conference of the International Communication Association (ICA)., p.p 1-19, 2013.

[9] T. Green, and J. Peloza, "How do consumers infer corporate social responsibility? The role of organisation size," Journal of Consumer Behaviour., vo. 13, pp. 282-293, 2014.

[10] S. Hoeffler, P. Bloom, and K. Keller, "Understanding stakeholder responses to corporate citizenship initiatives: managerial guidelines and research directions," Journal of Public Policy and Marketing., vol. 29, no. 1, pp. 78-88, 2010.

[11] C. B. Bhattacharya, and S. Sen, "Consumer-company identification: a framework for understanding consumers' relationships with companies," Journal of Marketing., vol. 67, no.2, pp. 76-88, 2003.

[12] T. Brown, and P. Dacin, "The company and the product: corporate associations and consumer product responses," Journal of Marketing., vol. 61, pp. 68-84, 1997.

[13] S. Sen, \& C. Bhattacharya, "Does doing good always lead to doing better? Consumer reactions to corporate social responsibility," Journal of Marketing Research., vol. 38, pp. 225-243, 2001.

[14] I. Maignan, and O. C. Ferrell, "Corporate social responsibility and marketing: an integrative framework," Journal of the Academy of Marketing Science., vol. 32, no. 1, pp. 3-19, 2004.

[15] J. M. Ricks, "An assessment of strategic corporate philanthropy on perceptions of brand equity variables," Journal of Consumer Marketing., vol. 22, no.3, pp. 121-34, 2005.

[16] A. McWilliams, and D. Siegel, "Corporate social responsibility: a theory of the firm perspective," Academy of Management Review., vol. 26, no. 1, pp. 117-27, 2001.

[17] M. E. Porter, and M. R. Kramer, "The competitive advantage of corporate philanthropy," Harvard Business Review., vol. 80, no.12, pp. 56-68, 2002.

[18] M. Orlitzky, F. L. Schmidt, and S. L. Rynes, "Corporate social and financial performance: a meta-analysis," Organization Studies., vol. 24 , no. 3, pp. 403-41, 2003.

[19] K. Gwinner, "A model of image creation and image transfer in event sponsorship", International Marketing Review., vol. 14, no. 3, pp.145$158,1997$.

[20] E. Bigné-Alcañiz, R. Currás-Pérez, C. Ruiz-Mafé, and S. Sanz-Blas "Cause-related marketing influence on consumer responses: The moderating effect of cause-brand fit," Journal of Marketing Communications., vol. 18, no. 4, pp. 265-283, 2012.

[21] G. R. Dowling, "Measuring corporate images: a review of alternative approaches," Journal of Business Research., vol. 17, no. 1, pp. 27-34, 1988. 
[22] C, M. Riordan, R. D. Gatewood, and J. B. Bill, "Corporate image: employee reactions and implications for managing corporate social performance," Journal of Business Ethics., vol. 16, no. 4, pp. 401-412, 1997.
[23] S. Hoeffler, K. L. Keller, "Building brand equity through corporate societal marketing," Journal of Public Policy \& Marketing., vol, 21, no. 1, pp. 78-88, 2002.

[24] Maholtra, Marketing Research: An Applied Approach. London :Pearson Education, 2007. 